\title{
THE EFFECT OF FLOWER REMOVAL ON THE GROWTH AND QUALITY OF BUSHES OF TWO ROSE (Rosa L.) VARIETIES
}

\author{
Piotr Baryła, Magdalena Kapłan, Piotr Kiczorowski, Marcela Krawiec, \\ Salwina Palonka, Stanisław Wociór, Irena Wójcik
}

\author{
Department of Seed Production and Nurseries, University of Life Sciences in Lublin \\ Leszczyńskiego 58, 20-068 Lublin, Poland \\ e-mail: agric@poczta.onet.pl
}

Received: 04.04.2013

\begin{abstract}
The present study was conducted during the period 2008-2011 in a production nursery without irrigation and established on grey-brown podzolic soil classified as soil class II. The study investigated the effect of regular flower removal on the growth and quality of bushes of the following rose (Rosa L.) varieties: a multi-flowered variety 'Arthur Bell' and a large-flowered variety 'Burgund'. In the case of the multi-flowered variety 'Arthur Bell', flower removal was found to have a significant effect on the number and total length of shoots growing from the bud union in bushes. On the other hand, this practice was not shown to have an effect on the growth and quality of bushes of the large-flowered variety 'Burgund'.

In the case of bushes of the studied varieties budded on Rosa multiflora Thunb. rootstock, the study showed significant differences in plant growth and branching between years. In 2009, after spring frosts that damaged young shoots and as an effect of a lower amount of rainfall by about $60 \mathrm{~mm}$ during the growing season, a much worse quality of rose bushes was obtained than in the other years.
\end{abstract}

Key words: Rosa L., nursery, flowering, plant branching, basal shoots

\section{INTRODUCTION}

Poland is a major producer of rose bushes in Europe. In the 1990's, the production of rose bushes was estimated at 15-18 million [1,2]. Poland was Europe's largest exporter of rose bushes [3]. 24 million rose bushes were exported in 1999, mainly to Denmark, Germany and the Netherlands. Questionnaire surveys conducted by M a r o s z [4] show that after 2000 there was a significant decline in the volume of produc- tion of these valuable plants. Compared to 2000, rose production in 2005 decreased by about $62 \%$, while in 2010 by more than $80 \%$. Both nursery growers and analysts agree that the reason for this regression was the deteriorating relation of income derived from rose production compared to other branches of ornamental plant nursery.

The quality and yield efficiency of nurserygrown rose bushes are determined by the selection of rootstocks and their quality, time and method of bud grafting, the physiological maturity of scions and rootstocks as well as plant fertilization and protection [514]. The available literature $[12,13,15]$ recommends the removal of flowers (deadheading) in flower beds after their senescence. This maintenance practice is designed to improve the regularity of flowering by reducing nutritional competition between fruit being formed and new growing canes. However, there is a lack of information on practical effects of flower removal in a rose nursery.

The aim of the present study was to investigate the effect of flower removal on the growth and quality of nursery-grown rose (Rosa L.) bushes var. 'Arthur Bell' and 'Burgund'.

\section{MATERIALS AND METHODS}

The study was conducted during the period 2008-2011 in a production nursery in the village of Płouszowice near Lublin. The experimental material consisted of two varieties budded on Rosa multiflora Thunb. rootstock. Rootstocks, with a root collar diameter of $3-5 \mathrm{~mm}$, were planted in the spring at a spacing 
of $0.15 \times 0.8 \mathrm{~m}$ on grey-brown podzolic soil classified as soil class II. A multi-flowered variety 'Arthur Bell', which produces numerous large fruits, and a large-flowered variety 'Burgund', which produces single poorly-developed fruits on the shoots, were selected for the study. The studied varieties belong to high vigour roses.

The experiment was set up in a randomized block design. It included 2 treatments for each variety in 5 replicates. Plots with 5 bushes in each were replicates. The control treatment and treatment in which flowers were removed were used for each variety. Flowers were removed regularly at the well-developed bud stage when petals emerged from sepals. During this period, flowers from the upper unlignified portion of the shoot can be pinched off very easily.
In the autumn after bushes were dug out, the root collar diameter and the length of main shoots growing from the bud union and of sylleptic shoots were measured. Based on these measurements, number of shoots, average shoot length and total length of shoots per bush were calculated.

The study results were statistically analysed using analysis of variance and Tukey's confidence intervals at a significance level of $\alpha=0.05 ; \mathrm{p}=0.95$.

\section{RESULTS}

Throughout the study period, flower removal was not found to significantly affect root collar diameter in the two rose varieties in question (Table 1).

Table 1

Effect of flower removal on root collar diameter in two rose varieties in 2008-2011

\begin{tabular}{|c|c|c|c|c|}
\hline \multirow{2}{*}{ Treatment } & \multicolumn{4}{|c|}{ Root collar diameter, mm } \\
\hline & 2008 & 2009 & 2011 & $\bar{x}$ \\
\hline \multicolumn{5}{|c|}{ 'Arthur Bell' } \\
\hline Control & $17.3 \mathrm{a}$ & $14.0 \mathrm{a}$ & $15.0 \mathrm{a}$ & $15.4 \mathrm{a}$ \\
\hline Flowers removed & $17.4 \mathrm{a}$ & $13.8 \mathrm{a}$ & $16.1 \mathrm{a}$ & $15.8 \mathrm{a}$ \\
\hline \multicolumn{5}{|c|}{ 'Burgund' } \\
\hline Control & $16.4 \mathrm{a}$ & $15.0 \mathrm{a}$ & $20.1 \mathrm{a}$ & $17.2 \mathrm{a}$ \\
\hline Flowers removed & $16.9 \mathrm{a}$ & $14.5 \mathrm{a}$ & $18.7 \mathrm{a}$ & $16.7 \mathrm{a}$ \\
\hline
\end{tabular}

Means within the column followed by the same letters are not significantly different at $p=0.05$

Throughout the study period, flower removal was not found to significantly affect root collar diameter in the two rose varieties in question (Table 1).

In 2008 and 2011, it was shown for 'Arthur Bell' rose bushes that flower removal slightly increased root collar diameter compared to the control treatment. In 2009 and 2011, it was found in the rose variety 'Burgund' that control bushes had slightly thicker root collars than plants in which flowers were removed.
Throughout the study period, the variety was shown to have a slight effect on the growth parameter studied; in 2008 var. 'Burgund' bushes had slightly thinner trunks than 'Arthur Bell', whereas in the other years a reverse relationship was demonstrated.

It was observed that in 2009 plants of the studied varieties developed the thinnest root collars.

Table 2

Effect of flower removal on the number of shoots growing from the bud union in bushes of two rose varieties in 2008-2011

\begin{tabular}{|c|c|c|c|c|}
\hline \multirow{2}{*}{ Treatment } & \multicolumn{4}{|c|}{ Number of shoots growing from the bud union, pcs. } \\
\hline & 2008 & 2009 & 2011 & $\bar{x}$ \\
\hline \multicolumn{5}{|c|}{ 'Arthur Bell' } \\
\hline Control & $4.1 \mathrm{a}$ & $2.7 \mathrm{a}$ & $4.7 b$ & $3.8 \mathrm{a}$ \\
\hline Flowers removed & $4.2 \mathrm{a}$ & $2.5 \mathrm{a}$ & $6.4 \mathrm{a}$ & $4.4 \mathrm{a}$ \\
\hline \multicolumn{5}{|c|}{ 'Burgund' } \\
\hline Control & $4.3 \mathrm{a}$ & $3.3 \mathrm{a}$ & $4.3 b$ & $4.0 \mathrm{a}$ \\
\hline Flowers removed & $4.4 \mathrm{a}$ & $2.7 \mathrm{a}$ & $4.1 b$ & $3.7 \mathrm{a}$ \\
\hline
\end{tabular}

Means within the column followed by the same letters are not significantly different at $p=0.05$ 
On average for the three-year period, flower removal increased the number of basal shoots by $16 \%$, while by $21 \%$ the total length of these shoots in the multi-flowered variety 'Arthur Bell'. This procedure did not affect the above-mentioned quality characteristics of var. "Burgund" (Tables 2 and 3 ).

In the case of var. 'Arthur Bell', it was shown only in 2011 that flower removal had a significant effect on the number of shoots growing out of the bud union and on the length of these shoots. A similar insignificant correlation was observed in 2008 for bushes of both varieties studied. In the other years, flower removal in 'Burgund' bushes did not affect the quality parameters evaluated.

During the study period, the variety was observed to slightly influence the quality parameters inve- stigated. In 2008 and 2009, var. 'Burgund' bushes had slightly more sylleptic shoots than 'Arthur Bell'. In the last year, a reverse correlation was observed, whereas in the case of control bushes these differences were significant. It was found that the total length of sylleptic shoots growing from the bud union was also dependent on the variety. In 2008 and 2009 in the control treatment, 'Burgund' bushes were characterized by a greater total length of lateral shoots than 'Arthur Bell'. A reverse relationship was observed in 2009 in bushes in which flowers were removed as well as in 2011. In the last year, these differences were significant in control plants.

In 2009 it was observed that bushes of the studied varieties had fewer shoots growing from the bud onion and a lower total length of these shoots than in the other years of the study (Tables 2 and 3).

Table 3

Effect of flower removal on the total length of lateral shoots in two rose varieties in 2008-2011

\begin{tabular}{|c|c|c|c|c|}
\hline \multirow{2}{*}{ Treatment } & \multicolumn{4}{|c|}{ Total length of shoots growing from the bud onion, $\mathrm{cm}$} \\
\hline & 2008 & 2009 & 2011 & $\bar{x}$ \\
\hline \multicolumn{5}{|c|}{ 'Arthur Bell' } \\
\hline Control & $224.7 \mathrm{a}$ & $171.0 \mathrm{a}$ & $270.2 b$ & $222.0 \mathrm{a}$ \\
\hline Flowers removed & $228.9 \mathrm{a}$ & $171.9 \mathrm{a}$ & $403.1 \mathrm{a}$ & $268.1 \mathrm{a}$ \\
\hline \multicolumn{5}{|c|}{ 'Burgund' } \\
\hline Control & $227.5 \mathrm{a}$ & $176.0 \mathrm{a}$ & $260.6 \mathrm{~b}$ & $221.2 \mathrm{a}$ \\
\hline Flowers removed & 238.9a & $171.3 \mathrm{a}$ & $253.6 \mathrm{~b}$ & $221.0 \mathrm{a}$ \\
\hline
\end{tabular}

Means within the column followed by the same letters are not significantly different at $p=0.05$

Table 4

Effect of flower removal on the number of sylleptic shoots in two rose varieties in 2008-2011

\begin{tabular}{|c|c|c|c|c|}
\hline \multirow{2}{*}{ Treatment } & \multicolumn{4}{|c|}{ Number of sylleptic shoots, pcs. } \\
\hline & 2008 & 2009 & 2011 & $\bar{x}$ \\
\hline \multicolumn{5}{|c|}{ 'Arthur Bell' } \\
\hline Control & $2.7 \mathrm{a}$ & $2.5 \mathrm{a}$ & $4.9 \mathrm{a}$ & $3.4 \mathrm{a}$ \\
\hline Flowers removed & $2.8 \mathrm{a}$ & $2.6 \mathrm{a}$ & $6.2 \mathrm{a}$ & $3.9 \mathrm{a}$ \\
\hline \multicolumn{5}{|c|}{ 'Burgund' } \\
\hline Control & $2.8 \mathrm{a}$ & $3.3 \mathrm{a}$ & $10.4 \mathrm{a}$ & $5.5 \mathrm{a}$ \\
\hline Flowers removed & $2.9 \mathrm{a}$ & $2.9 \mathrm{a}$ & $12.4 \mathrm{a}$ & $6.0 \mathrm{a}$ \\
\hline
\end{tabular}

Means within the column followed by the same letters are not significantly different at $p=0.05$

Flower removal was not shown to significantly affect the number of sylleptic shoots in the rose varieties investigated (Table 4).

In each year of the study, var. 'Arthur Bell' bushes in which flowers were removed were found to have a greater number of sylleptic shoots than in control plants, but these differences were not significant. In the case of var. 'Burgund', it was observed that in 2008 and 2011 the flower removal procedure promoted the development of a higher number of sylleptic shoots compared to control bushes.

The growth parameter studied was dependent on the variety throughout the study period. 'Burgund' bushes were found to have a greater number of sylleptic shoots than 'Arthur Bell'.

It was observed that in 2011 bushes of the varieties under study had more sylleptic shoots than in the other years of the study (Table 4). 
Table 5

Effect of flower removal on sylleptic shoot length in two rose varieties in 2008-2011

\begin{tabular}{ccccc}
\hline \multirow{2}{*}{ Treatment } & \multicolumn{4}{c}{ Sylleptic shoot length, cm } \\
\cline { 2 - 5 } & 2008 & 2009 & 2011 & $\bar{x}$ \\
\hline \multicolumn{5}{c}{ 'Arthur Bell' } \\
\hline Control & $22.5 \mathrm{a}$ & $35.1 \mathrm{a}$ & $18.5 \mathrm{a}$ & $25.3 \mathrm{a}$ \\
Flowers removed & $25.1 \mathrm{a}$ & $34.8 \mathrm{a}$ & $17.1 \mathrm{a}$ & $25.7 \mathrm{a}$ \\
\hline \multicolumn{5}{c}{} \\
Control & 'Burgund' & $30.6 \mathrm{a}$ \\
Flowers removed & $25.6 \mathrm{a}$ & $38.0 \mathrm{a}$ & $28.2 \mathrm{a}$ & $30.8 \mathrm{a}$ \\
\hline
\end{tabular}

Means within the column followed by the same letters are not significantly different at $p=0.05$

Flower removal in bushes of the two rose varieties in question did not have a significant effect on sylleptic shoot length (Table 5). The variety 'Burgund' was characterized by longer shoots compared to var. 'Arthur Bell'.

In 2008 'Arthur Bell' bushes in which flowers were removed had sylleptic shoots longer than in control plants, while in the other years these shoots were shorter. In var. 'Burgund' the flower removal procedure promoted the development of longer sylleptic shoots only in 2011.

During the study period, the variety was observed to affect the parameter studied. Bushes of the variety 'Burgund' had longer shoots than 'Arthur Bell'.

Regardless of the variety, the longest sylleptic shoots were obtained in 2009.

\section{DISCUSSION}

The branching ability of roses is one of the most important traits that determine the quality of nursery material. It depends on the variety and budding method [12] as well as on rootstock quality and fertilization $[7,16]$, but to a lesser extent on scion quality $[10,11,13]$. The studies of the above-mentioned authors showed significant differences in branching ability between years. A similar relationship was found in the present study. Moreover, it was demonstrated that in the case of multi-flowered rose varieties, such as 'Arthur Bell', the mitigation of nutritional competition between fruit being formed and shoots growing from the bud union by the removal of flowers can improve the ability of early development of shoots growing out of the place of budding under nursery conditions, which are well lignified before bushes are dug out. The number of structural shoots, that is, flower yield in rose, can depend on the structure (volume) of the rootstock root system $[17,18]$.

The results of the present study showed that the smallest root collar diameter, the lowest number of shoots growing from the bud union in the studied varieties and the lowest total length of these shoots were obtained in 2009. An analysis of weather conditions demonstrates that the amount of rainfall during the 2009 growing season was lower by about $60 \mathrm{~mm}$ than in the other years. Other authors have also found a great variation in the quality of bushes between years $[13,16]$.

Furthermore, detailed observations of rose bushes showed that after the period of April frosts in 2009 (on 20 April the ground temperature dropped to $-5.2^{\circ} \mathrm{C}$, while in the next 4 days it continued below $-3^{\circ} \mathrm{C}$ ), young developing canes were severely damaged. The canes growing from the bud union died out. After the bud patch was cut, strands of brown phloem and cambium could be seen. The plants regenerated the damage slowly. Numerous canes broke during the further growth stages of rose bushes. In 2008 no late April or May frosts were observed. On the other hand, in 2011 frosts at the beginning of May did not exceed $-2^{\circ} \mathrm{C}$ and only caused the youngest leaves to die back. The above presented observations and the literature data $[12,13,16]$ are evidence that rose production in the conditions of the Lublin region presents a high risk.

These study results, which demonstrate that the quality of multi-flowered rose bushes can be improved by removing flowers, were obtained on soil class II. It can be presumed that this practice can produce much better practical effects on poorer soils.

\section{CONCLUSIONS}

1. In the case of the multi-flowered variety "Arthur Bell', in 2011 flower removal was shown to have a significant effect on the number and total length of basal shoots growing from the bud union.

2. Flower removal was not found to significantly affect root collar diameter in the rose varieties studied.

3. The growth and branching of roses in a non-irrigated nursery varied between years. Weather conditions during the growing season were the main reason for this variation. 
4. In the case of nurseries with multi-flowered roses, flower removal can be recommended, especially during the first flowering period, as a practice that improves the quality of rose bushes by accelerating the growth of basal shoots that grow early from the bud union and by increasing their number.

\section{Acknowledgements}

Research supported by the Ministry of Science and Higher Education of Poland as part of the statutory activities of the Department of Seed Production and Nurseries, University of Life Sciences in Lublin.

\section{Authors' contributions}

The following declarations about authors' contributions to the research have been made: concept of the study: SW; field research: SW, PK, SP, IW; data analyses: SW, PB, MK, MK; references: SW, PB, MK, PK, SP; writing the manuscript: SW, PB, MK, IW.

\section{REFERENCES}

1. Hetman J, Jabłońska L. Kierunki rozwoju produkcji roślin ozdobnych w Polsce na progu XXI wieku. In: Proceedings of the "Strategia rozwoju polskiego ogrodnictwa do 2010 roku" conference. Lublin: 11-12 grudnia 1997: 34-38.

2. Wy bicki Z. Produkcja krzewów róż w Polsce - upadek czy problemy adaptacyjne. In: Proceedings of the "Róże w szkółce i pod osłonami” conference. Skierniewice: 30 marca 2001: 45-59.

3. S moleński P, Stępka G. Niekorzystny bilans handlu kwiatami. Owoce Warzywa Kwiaty. 2001; 23: 4-5.

4. Marosz A. Zmiany w strukturze produkcji szkółkarskiego materiału w Polsce w latach 2000-2010. In: Proceedings of the "Nowości w nawożeniu i ochronie roślin szkółkarskich" conference. Darłowo: 4-5 listopada 2010: 5-10.

5. Chu CY. Budded cuttings for propagating roses. Sci Hortic. 1990; 43(1-2): 163-168. http://dx.doi.org/10.1016/ 0304-4238(90)90047-I

6. Kool MTN, van de Pol PA. Aspects of growth, analysed for Rosa hybrida "Motrea" as affected by six rootstocks. Gartenbauwissenschaft. 1992; 57(3): 120-125.

7. Marcelis-van Acker CAM. Morphological study of the formation and development of basal shoots in roses. Sci Hortic. 1993; 54(2): 143-152. http://dx.doi.org/10. 1016/0304-4238(93)90062-U

8. Hetman J, Monder MJ. Wpływ jakości podkładki i zrazów na wyniki okulizacji dwóch odmian uprawnych z grupy róż wielkokwiatowych. Zesz Probl Post Nauk Rol. 2003; 491: 79-90.

9. Hetman J, Monder MJ. Wpływ jakości podkładki i zrazów na wyniki okulizacji dwóch odmian róż z grupy wielokwiatowych. Acta Sci Pol Hortorum Cultus. 2003; 2(2): 33-41.

10. Hetman J, Monder MJ. Wpływ dojrzałości zrazów oraz umiejscowienia oczka na pędzie na wzrost i jakość uzyskanych krzewów dwóch odmian róż z grupy wielkokwiatowych. Część I. Parametry wzrostu krzewów [The influence of ripeness of scions and bud place on shoot on the quality of the obtained shrubs of two Rosa thea hybrida cultivars Part I. Growth parameters of the obtained shrub roses]. Acta Sci Pol Hortorum Cultus. 2004; 3(2): 13-21.

11. Hetman J, Monder MJ. Wpływ dojrzałości zrazów oraz umiejscowienia oczka na pędzie na wzrost i jakość uzyskanych krzewów dwóch odmian róż z grupy wielkokwiatowych. Część II. Jakość krzewów The influence of ripeness of scions and bud place on shoot on the quality of the obtained shrubs of two Rosa thea hybrida cultivars. Part II]. Acta Sci Pol Hortorum Cultus. 2004; 3(2): 23-31.

12. Pudelska K. Oddziaływanie podkładek na wzrost i kwitnienie odmian uprawnych róży. Lublin: University of Life Sciences in Lublin Press; 2003. (vol 269).

13. Monder MJ. Wpływ jakości podkładki i zrazów na wzrost i kwitnienie uprawnych odmian róży [PhD thesis]. Lublin: University of Life Sciences in Lublin; 2005.

14. Chochura P. Nawożenie roślin szkółkarskich azotem. In: Proceedings of the "Nowości w nawożeniu i ochronie roślin szkółkarskich" conference. Darłowo: 4-5 listopada 2010: 11-26.

15. Monder M J.Róże. Warsaw: Powszechne Wydawnictwo Rolniczne i Leśne; 2006.

16. Falińska-Król J. Wpływ zabiegów agrotechnicznych na wzrost podkładek róż [PhD thesis]. Lublin: University of Life Sciences in Lublin; 2000.

17. De Vries DP, Dubois LAM. Relations between basal bottom breaks and harvested shoots in own-rooted hybrid tea rose seedlings and their clones. Gartenbauwissenschaft. 1983;48(5):189-192.

18. Han YY, Sim YG, Song IK, Yoon JT, Choi B S . Effect of seeding, transplanting date and diameter of Rosa multiflora with rootstock nursery on the growth and quality of rose budding. J Agri Sci. 1995; 37(2): 432-437.

\section{Wpływ usuwania kwiatów na wzrost i jakość krzewów dwóch odmian róży (Rosa L.)}

\section{Streszczenie}

Badania wykonano w latach 2008-2011 w szkółce produkcyjnej nie posiadającej nawodnienia, rosnącej na glebie płowej zaliczonej do drugiej klasy bonitacyjnej. Badano wpływ systematycznego usuwania kwiatów na wzrost i jakość krzewów róży (Rosa L.) odmiany wielokwiatowej 'Arthur Bell' i odmiany wielkokwiatowej 'Burgund'. W przypadku odmiany wielokwiatowej 'Arthur Bell' stwierdzono istotny wpływ usuwania kwiatów na liczbę i sumaryczną długość pędów wyrastających na krzewach z miejsca okulizacji. Nie wykazano natomiast wpływu tego zabiegu na wzrost i jakość krzewów wielkokwiatowej odmiany 'Burgund'. 
W przypadku krzewów badanych odmian okulizowanych na podkładce Rosa multiflora Thunb. wykazano znaczne różnice dotyczące wzrostu i krzewienia się roślin między latami badań. W 2009 roku po przymrozkach wiosennych uszkadzających młode pędy oraz w efekcie mniejszej o około $60 \mathrm{~mm}$ ilości opadów w okresie wegetacji uzyskano znacznie gorszą jakość krzewów róż niż w pozostałych latach.

Handling Editor: Elżbieta Weryszko-Chmielewska

This is an Open Access digital version of the article distributed under the terms of the Creative Commons Attribution 3.0 License (creativecommons.org/licenses/by/3.0/), which permits redistribution, commercial and non-commercial, provided that the article is properly cited.

(CThe Author(s) 2014 Published by Polish Botanical Society 